\title{
Levels of trace metals in water and sediment from Tyume River and its effects on an irrigated farmland
}

\author{
OR Awofolu ${ }^{1 *}, \mathrm{Z}$ Mbolekwa $^{1}, \mathrm{~V}$ Mtshemla ${ }^{1}$ and OS Fatoki ${ }^{2}$ \\ ${ }^{1}$ Department of Chemistry, University of Fort Hare, Alice 5700, South Africa \\ ${ }^{2}$ Research \& Development Office, University of Venda, Thohoyandou 0950, South Africa
}

\begin{abstract}
Levels of trace metals (Cd, $\mathrm{Pb}, \mathrm{Co}, \mathrm{Zn} \mathrm{Cu}$ and $\mathrm{Ni}$ ) were determined in water and sediment from the Tyume River. Occurrence of these metals in vegetables and soil from a nearby farmland as a result of irrigation with the river water was also investigated. Higher levels of $\mathrm{Cd}(0.038 \pm 0.004$ to $0.044 \pm 0.003 \mathrm{mg} / \ell)$ and $\mathrm{Pb}(0.021 \pm 0.004$ to $0.035 \pm 0.001 \mathrm{mg} / \ell)$ were found in the river water, which may be detrimental to the "health" of the aquatic ecosystem and the rural communities that utilise the river water for domestic purposes without any treatment. Some of these metals were also detected in the soil and vegetables cultivated on the farmland which indicates a possible contribution from the river water.
\end{abstract}

Keywords: trace metals, water, sediment, farmland, Tyume River

\section{Introduction}

The presence of toxic metals such as $\mathrm{Pb}$ and $\mathrm{Cd}$ in the environment has been a source of worry to environmentalists, government agencies and health practitioners. This is mainly due to their health implications since they are non-essential metals of no benefit to humans (Tyler, 1981; Borgman, 1983). The presence of these metals in the aquatic ecosystem has far-reaching implications directly to the biota and indirectly to man. The Eastern Cape Province is noted for rural agricultural practices both for subsistence and medium-scale commercial farming.

There are no potable water supplies in some of these catchment areas, hence dependence on water sources mainly from ground- and surface waters for domestic, irrigation and livestock activities. Obviously, the chemical status of the river would have its influence on the receiving land, which might possibly reflect on the produce cultivated on such land.

Trace metals have been referred to as common pollutants, which are widely distributed in the environment with sources mainly from the weathering of minerals and soils (Merian, 1991; O’ Neil, 1993). However, the level of these metals in the environment has increased tremendously in the past decades as a result of human inputs and activities (Preuss and Kollman, 1974; Prater, 1975; Merian, 1991).

Cadmium is one of the most toxic elements with reported carcinogenic effects in humans (Goering et al., 1994). It accumulates mainly in the kidney and liver and high concentrations have been found to lead to chronic kidney dysfunction. It induces cell injury and death by interfering with calcium $(\mathrm{Ca})$ regulation in biological systems. It has been found to be toxic to fish and other aquatic organisms (Woodworth and Pascoe, 1982). Cadmium has been implicated in endocrine disrupting activities, which could pose serious health problems. Apart from the health implication, the metal (Cd), together with other elements, e.g. Zn form a toxic “soup"

* To whom all correspondence should be addressed.

皿+2740 602-2094; fax:+27

e-mail:_oawofolu@ufh.ac.za, orawofolu3@yahoo.com

Received 7 May 2004; accepted in revised form 25 October 2004. that often acts synergistically. Sources of Cd include wastes from Cd-based batteries, incinerators and runoff from agricultural soils where phosphate fertilisers are used since $\mathrm{Cd}$ is a common impurity in phosphate fertilisers (Stoeppler, 1991).

The United States Environmental Protection Agency has classified $\mathrm{Pb}$ as being potentially hazardous and toxic to most forms of life (USEPA, 1986a). It has been found to be responsible for quite a number of ailments in humans such as chronic neurological disorders especially in foetuses and children. Automobile exhaust fumes have been reported to account for about $50 \%$ of the total inorganic $\mathrm{Pb}$ absorbed by human beings (Mohan and Hosetti, 1998). Other inputs of $\mathrm{Pb}$ into the environment are from used dry-cell batteries, from sewage effluent, runoff of wastes and atmospheric deposition.

Although $\mathrm{Zn}$ has been found to have low toxicity to man, prolonged consumption of large doses can result in some health complications such as fatigue, dizziness, and neutropenia (Hess and Schmid, 2002). Some literature sources have also revealed that $\mathrm{Zn}$ could be toxic to some aquatic organisms such as fish (Alabaster and Lloyd, 1980). Certain metals such as $\mathrm{Cu}$ and $\mathrm{Co}$ are classified as essential to life due to their involvement in certain physiological processes. Elevated levels of these, however, have been found to be toxic (Spear, 1981). Copper, Zn and Co form the essential group of metals required for some metabolic activities in organisms. Toxicological effects of large amounts of Co include vasodilation, flushing and cardiomyopathy in humans and animals (Teo and Chen, 2001). Their interest in this study lies between essentiality and possible toxicity when present at elevated levels.

Nickel also is a naturally occurring element found in a number of mineral ores including $\mathrm{Ni}$ sulphides, oxides and silicates. It is present in the enzyme urease and as such is considered to be essential to plants and some domestic animals. The essentiality of Ni to man has not been demonstrated (Teo and Chen, 2001). Its properties such as strength, corrosion resistance, high ductility, good thermal and electric conductivity and catalytic properties enhance its commercial importance and applications. However, Ni-related health effects such as renal, cardiovascular, reproductive, and immunological effects have been reported in animals. Toxicity of $\mathrm{Ni}$ to rainbow trout has been reported (Pane et al., 2003). Its toxic 


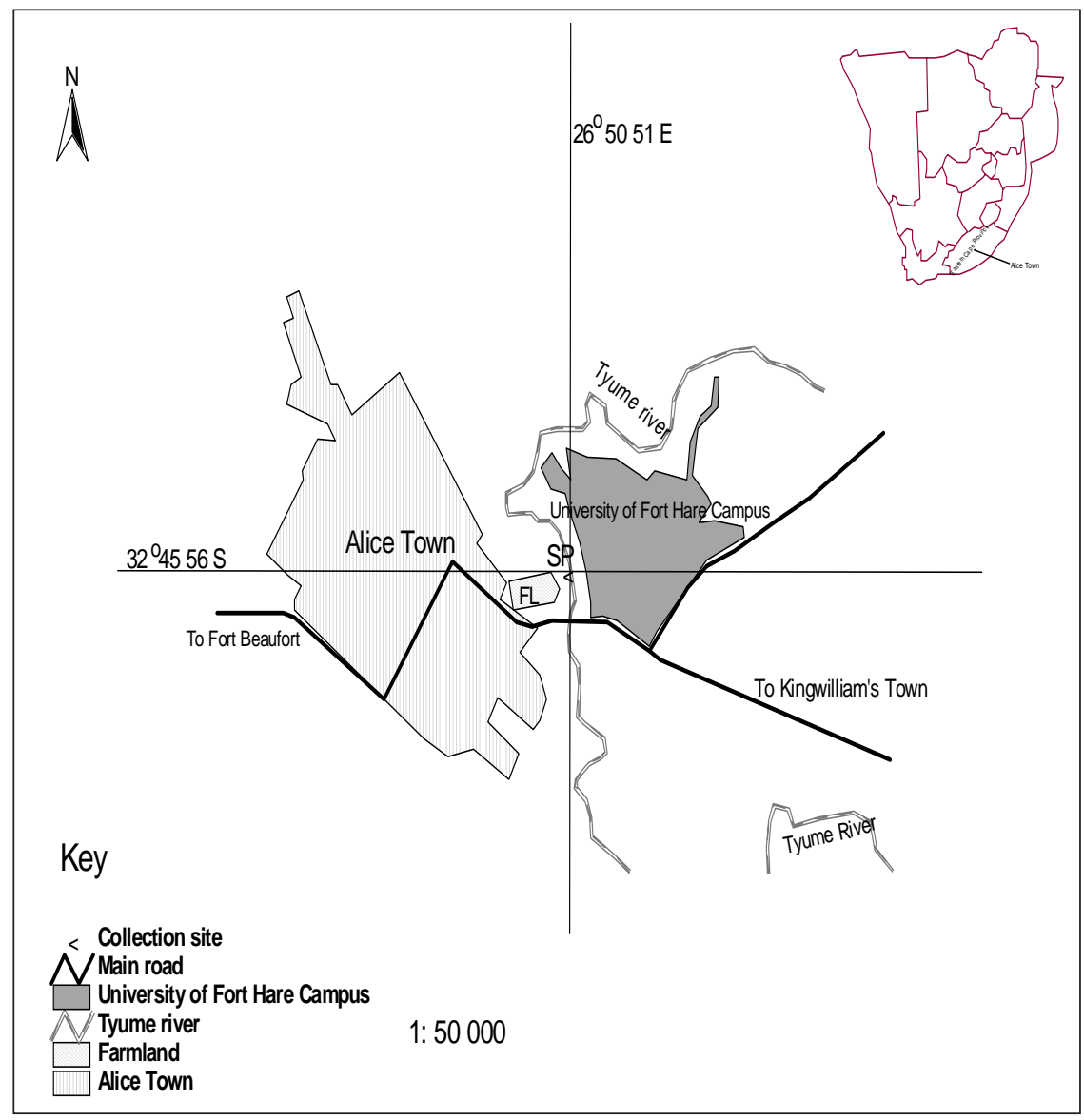

Figure 1

Map of the sampling sites. $F L=$ farm land, $\mathrm{SP}=$ sampling point

(Tyume River) effects in man are related to dermal, lung and nasal sinus cancers. Trace metals have been determined in potable water (Holynska et al., 1996; Gulson et al., 1997; Garcia et al., 1999) and fresh- and marine waters (Fatoki et al., 2002; Fatoki, 1993; Batterham et al., 1997; Fiaccabrino et al., 1998; Hall et al., 2002), using varieties of methods. Although water is commonly employed as a pollution indicator by trace metals, sediment can also provide a deeper insight into the long-term pollution state of the water-body. Sediment has been described as a ready sink or reservoir of pollutants including trace metals where they concentrate according to the level of pollution (Becker et al., 2001; Onyari et al., 2003). The need to assess the state and quality of the Tyume River and the sediment in terms of its metallic load becomes imperative since water from the river is being used for domestic, irrigation and livestock activities by people living in the catchment area, in view of the health implications that cut across the food strata.

This research work reports the levels of trace metals $(\mathrm{Cd}, \mathrm{Pb}$, $\mathrm{Ni}, \mathrm{Zn}, \mathrm{Co}$ and $\mathrm{Cu}$ ) in Tyume River water, sediment and some physical parameters on the one hand and levels in vegetable crops (spinach and cabbage) and soil from a nearby farmland irrigated with water from the river, which also supports a wide population.

\section{Description of study area}

The Tyume River (Fig. 1) is located within the Eastern Cape Province of South Africa. It flows from the upper part of the Eastern Cape, passing through the lower coast escarpment down to Alice through several rural locations and finally linking the Buffalo River and Keiskamma River. Close proximity of the river to these locations made it ideal for utilisation for domestic activities where piped potable water is not available. The farmland is located about
$50 \mathrm{~m}$ from the river channel and about $200 \mathrm{~m}$ away from the eastern side of the University of Fort Hare, which created a ready and regular source of water for irrigation of the land. The farmland is cultivated by people in the locality. Cabbage, spinach and to a lesser extent carrot are the main cultivated crops. These are sold to individuals and retailers who in turn sell them at the Alice general market.

\section{Materials and methods}

\section{Samples and sampling sites}

Sampling sites for water and sediment and for soil and vegetables are shown in Fig. 1. Water and sediment samples were collected from the river-bank closest to where water is being pumped onto the farmland. Vegetables (cabbage and spinach) were purchased directly from farmers, requesting vegetable stalks from different areas of the farm. Sample containers were thoroughly washed with detergent, rinsed with water and then with distilled water before soaking in 5\% $\mathrm{HNO}_{3}$ for about $24 \mathrm{~h}$. Containers were finally rinsed with doubledistilled water before being used for sampling.

Water and sediment samples were collected following the standard procedure described by DWAF (1992). Water samples were kept cooled en route to the laboratory and stored at $4^{\circ} \mathrm{C}$ while sediment samples were kept frozen at $-18^{\circ} \mathrm{C}$ until analysed. Treatment and analysis of samples usually took place within $24 \mathrm{~h}$ of collection. Sediment samples were allowed to defrost, then air-dried in a circulating oven at $30^{\circ} \mathrm{C}$ and thereafter sieved mechanically using a $2 \mathrm{~mm}$ sieve. All determinations were based on the fine sediment particles obtained since metals are known to adhere to these fine particles. Vegetable samples were placed in polyethylene bags, labelled and taken to the laboratory while soil samples were 
randomly collected from the 0 to 50 mm layer without profiling using a soil trowel from the farmland, placed in a plastic container and also stored until analysed. Plant samples were thoroughly rinsed with water and then with double-distilled water to remove any attached soil particles, cut into smaller portions and placed in a large crucible where they were oven-dried at $60^{\circ} \mathrm{C}$ overnight. The dried plants were ground into fine particles using a clean acid-washed mortar and pestle. A portion of the homogeneous soil samples were also airdried by circulating air in the oven overnight and sieved mechanically using a $2 \mathrm{~mm}$ sieve. All metal determinations were based on these fine soil particles.

\section{Physical parameters}

The $\mathrm{pH}$ of river water samples was determined directly on-site with the $\mathrm{pH}$ meter 330 supplied by Merck NT Laboratory Pty Ltd before preserving with $5 \mathrm{~m} \ell$ of concentrated $\mathrm{HNO}_{3}$. The moisture content and organic matter of soil and sediment samples (using the ferrous ammonium sulphate titration method) were determined in the laboratory by the procedure described by Radojevic and Bashkin (1999).

\section{Limits of detection and quality assurance}

Limits of detection of the analysed metals were determined as thrice the standard deviation $(3 \sigma)$ of their lowest detectable concentrations by FAAS from the mean of six replicate analyses. Good linearity was obtained from the calibration curves prepared from 1000 $\mathrm{mg} / \ell$ of each metal standard from BDH laboratory, England.

The open-beaker digestion method (OBD) as described in DWAF (1992) and extractive concentration methods according to Van Loon (1982) were evaluated for the quality assurance of water samples. The spiking method of double-distilled water at fortification levels of $0.05 \mathrm{mg} / \ell \mathrm{Cd}$ and $\mathrm{Pb}, 5.0 \mathrm{mg} / \ell$ of $\mathrm{Zn}, \mathrm{Cu}$, Co and $\mathrm{Ni}$ was employed. For the extractive concentration method, ammonium pyrollidine dithiocarbamate (APDC) and sodium diethyldithiocarbamate (NaDDC) were evaluated for their chelating ability using methyl isobutyl ketone (MIBK) as the extracting solvent. Triplicate analyses of each metal for the two methods together with a blank were carried out.

The quality assurance for vegetable samples was also conducted through the spiking method, evaluating a sample digestion process using both hotplate (HP) and microwaveassisted digestion (MAD). A chemical analysis procedure described by (Fatoki and Mathabatha, 2001) was applied as follows: $0.5 \mathrm{~g}$ of the sieved pre-digested plant samples (cabbage and spinach) was weighed into a 100 $\mathrm{m} \ell$ beaker and spiked with metal standards at fortification levels as in water analysis. $5 \mathrm{~m} \ell$ of concentrated $\mathrm{HNO}_{3}$ was added and the solution was then boiled gently on a hotplate for about $30 \mathrm{~min}$. The beaker was cooled and $2 \mathrm{~m} \ell$ of $\mathrm{HClO}_{4}, 5 \mathrm{~m} \ell$ of $\mathrm{HNO}_{3}$ and $5 \mathrm{~m} \ell$ of $\mathrm{HF}$ were added and the mixture heated to near dryness.

The beaker wall was washed with $5 \mathrm{~m} \ell$ of double-distilled water, heated gently and $10 \mathrm{~m} \ell \mathrm{HNO}_{3}$ added. The solution was transferred into a $50 \mathrm{~m} \ell$ standard flask and made up to volume with double-distilled water, which was analysed using flame atomic absorption spectroscopy (FAAS). Triplicate digestion and analyses of each sample together with the blank were carried out.

For MAD the beaker was partially covered with a watch-glass, placed in the oven (R-340C Sharp domestic microwave) and then heated at 30\% microwave energy level (medium) for 3, 5 and 8 min respectively for the three acidification/digestion steps (Fatoki and Mathabatha, 2001) in the fume cupboard. The digest liquor was allowed to cool, then filtered into $50 \mathrm{~m} \ell$ standard flask using 0.45 $\mu \mathrm{m}$ Millipore filter paper and analysed by FAAS. Triplicate digestion of each sample was also carried out together with the blank.

For soil and sediment samples, the quality assurance protocol was carried out following the procedure described by Shriadah, 1999. Briefly, $5 \mathrm{~g}$ of pre-digested soil and sediment samples were separately placed in a $250 \mathrm{~m} \ell$ beaker, spiked with metal standards at the fortification level described above and $3 \mathrm{m \ell}$ of $30 \% \mathrm{H}_{2} \mathrm{O}_{2}$ added. This was left to stand for $60 \mathrm{~min}$ until the vigorous reaction ceased. $75 \mathrm{~m} \ell$ of $0.5 \mathrm{M}$ solution of $\mathrm{HCl}$ was added and the content heated gently at low heat on the hotplate for about $2 \mathrm{~h}$. The digest liquor was allowed to cool, filtered and brought to $100 \mathrm{~m} \ell$ with the acid solution. Triplicate digestion of each sample together with the blank was performed. This method has been widely applied in environmental investigations because it removes the metal fractions associated with carbonates, sulphides, soluble salts, organic matter held and Fe-Mn oxide phase (Agemian and Chau, 1976; Tessier et al., 1979).

\section{Analysis of samples}

Open-beaker digestion (OBD) protocols were employed for the chemical analyses of water samples. Microwave-assisted digestion (MAD) was used for the vegetable samples while the procedure described by Shriadah, 1999 was applied to soil and sediment samples due to their relatively high recoveries and reproducibility. Three replicate digestions were carried out for each sample.

\section{Results and discussion}

The limits of detection of the analysed metals and the percentage recoveries of spiked double-distilled water with metal standards using the OBD and liquid-liquid extraction methods (LLE) are presented in Table 1 . The detection limits are 0.002, 0.003, 0.04, 0.05, 0.02 and $0.02 \mathrm{mg} / \ell$ for $\mathrm{Cd}, \mathrm{Pb}, \mathrm{Co}, \mathrm{Zn}, \mathrm{Cu}$ and Ni respectively.

TABLE1

Detection limits (mg/l) and *mean \% recoveries ( $\pm S D)$ of trace metal standards added to double-distilled water

\begin{tabular}{|c|c|c|c|c|c|}
\hline Metals & $\begin{array}{c}\mathrm{DL} \\
(\mathrm{mg} / \mathrm{l})\end{array}$ & $\begin{array}{l}\text { Spiked } \\
\text { conc. } \\
\text { (mg/l) }\end{array}$ & OBD & ${ }^{1}$ LLE & ${ }^{2}$ LLE \\
\hline $\mathrm{Cd}$ & 0.002 & 0.05 & $93.4 \pm 0.003$ & $80.0 \pm 0.001$ & $95.5 \pm 0.005$ \\
\hline $\mathrm{Pb}$ & 0.003 & 0.05 & $99.0 \pm 0.004$ & $110.3 \pm 0.006$ & $91.2 \pm 0.003$ \\
\hline Co & 0.04 & 0.5 & $91.7 \pm 0.002$ & $71.2 \pm 0.002$ & $77.8 \pm 0.003$ \\
\hline $\mathrm{Zn}$ & 0.05 & 0.5 & $97.6 \pm 0.001$ & $73.2 \pm 0.002$ & $80.6 \pm 0.002$ \\
\hline $\mathrm{Cu}$ & 0.02 & 0.5 & $91.6 \pm 0.003$ & $80.7 \pm 0.004$ & $75.3 \pm 0.001$ \\
\hline $\mathrm{Ni}$ & 0.02 & 0.5 & $98.2 \pm 0.005$ & $75.2 \pm 0.005$ & $87.1 \pm 0.004$ \\
\hline
\end{tabular}

DL $=$ Detection limit, $*$ Values are mean of triplicate analyses, LLE $=$ Liquid/liquid solvent extraction, O.B.D = Open-beaker digestion, ${ }^{1}$ LLE using sodium diethyldithiocarbamate as chelating agent, ${ }^{2} \mathrm{LLE}$ using ammonium pyrollidinedithiocarbamate as chelating agent, $\mathrm{SD}=$ standard deviation. 


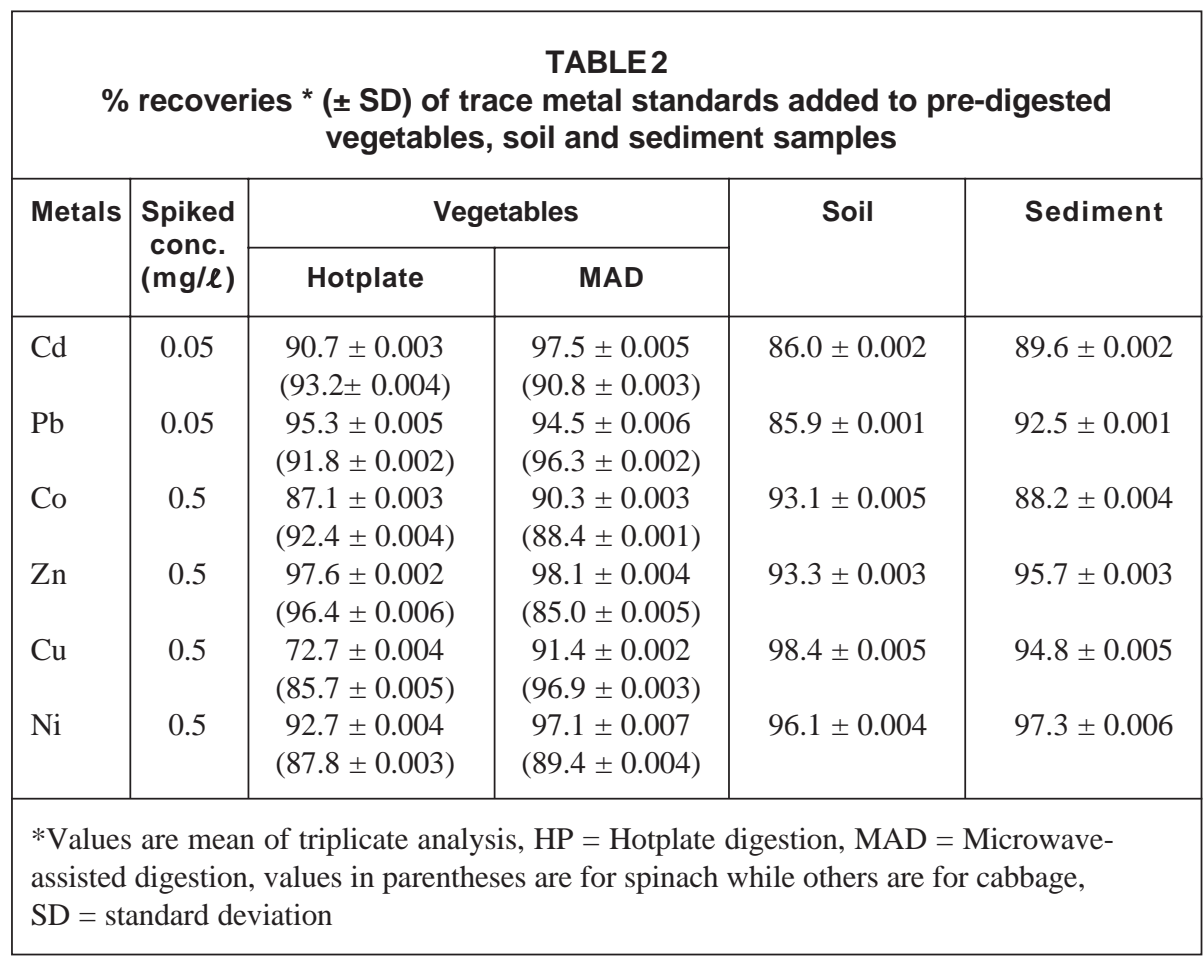

recoveries were obtained in both and the method was applied to metallic determination of environmental samples. Mean recoveries from spiked pre-digested spinach and cabbage using a hotplate as a heat source were $85.7 \pm 0.005$ to $96.4 \pm 0.006$ and 72.7 \pm 0.004 to $97.6 \pm 0.002$ respectively while that using microwave-assisted digestion for both samples ranged from $85.0 \pm 0.005$ to $96.9 \pm 0.003$ and $90.3 \pm 0.003$ to $98.1 \pm 0.004$ respectively. Acceptable recoveries were also obtained for both methods; however, MAD was applied for routine analyses of vegetable samples due to shorter analysis time.

Results of trace metal analyses in Tyume River water and sediment are presented in Table 3. The mean concentrations of $\mathrm{Cd}$ in water ranged from $0.030 \pm 0.002$ to $0.044 \pm 0.003$ $\mathrm{mg} / \ell$ while that of sediment varied between trace and $0.005 \pm 0.003 \mathrm{mg} /$ $\mathrm{kg}$. The range obtained from river water was higher than the tentative South African Target Water Quality

TABLE 3

Levels of trace metals *(mg/l $\pm \mathrm{SD})$ in river water and sediment $(\mathrm{mg} / \mathrm{kg} \pm \mathrm{SD})$ samples

\begin{tabular}{|l|c|c|c|c|}
\hline \multirow{3}{*}{ Metals } & \multicolumn{4}{|c|}{ Sampling dates } \\
\cline { 2 - 5 } & $\mathbf{2 2 / 0 7 / 0 3}$ & $\mathbf{2 5 / 0 8 / 0 3}$ & $\mathbf{1 9 / 0 9 / 0 3}$ & $\mathbf{0 2 / 1 0 / 0 3}$ \\
\hline \multirow{2}{*}{$\mathrm{Cd}$} & $0.030 \pm 0.002$ & $0.044 \pm 0.003$ & $0.038 \pm 0.004$ & $0.041 \pm 0.001$ \\
& $(0.002 \pm 0.007)$ & $(0.005 \pm 0.003)$ & (Trace) & (Trace) \\
$\mathrm{Pb}$ & $0.024 \pm 0.004$ & $0.035 \pm 0.001$ & $0.021 \pm 0.004$ & $0.033 \pm 0.004$ \\
& $(0.042 \pm 0.006)$ & $(0.067 \pm 0.003)$ & $(0.040 \pm 0.005)$ & $(0.059 \pm 0.007)$ \\
$\mathrm{Co}$ & $0.059 \pm 0.001$ & $0.062 \pm 0.002$ & Trace & Trace \\
& $(0.102 \pm 0.008)$ & $(0.312 \pm 0.04)$ & (Trace) & (Trace) \\
$\mathrm{Zn}$ & $0.018 \pm 0.001$ & $0.083 \pm 0.006$ & $0.431 \pm 0.002$ & $0.097 \pm 0.005$ \\
& $(0.080 \pm 0.003)$ & $(0.491 \pm 0.004)$ & $(0.393 \pm 0.007)$ & $(0.353 \pm 0.002)$ \\
$\mathrm{Cu}$ & $0.383 \pm 0.006$ & $0.387 \pm 0.002$ & Trace & Trace \\
& $(0.444 \pm 0.003)$ & $(0.496 \pm 0.004)$ & $(0.082 \pm 0.007)$ & $(0.094 \pm 0.002)$ \\
$\mathrm{Ni}$ & $1.777 \pm 0.002$ & $0.738 \pm 0.009$ & $1.357 \pm 0.005$ & $0.201 \pm 0.003$ \\
& $(0.401 \pm 0.006)$ & $(0.579 \pm 0.002)$ & $(0.438 \pm 0.005)$ & $(0.981 \pm 0.007)$ \\
& & &
\end{tabular}

*Values are mean of triplicate analyses; values in parentheses are for sediment samples

Range (TQWR) guideline of 0 to 0.005 $\mathrm{mg} / \ell$ in river water for domestic use(DWAF, 1996a), higher than $0.005 \mathrm{mg} / \ell$ as the maximum contaminant level (MCL) (USEPA, 1986b) and also higher than the South African TWQR of 0 to $0.01 \mathrm{mg} / \ell$ for irrigation and livestock watering (DWAF, 1996c).

This showed that water from the river is unsuitable for these activities with regards to the value obtained in this study, which could have chronic health effects on various users. However, the levels of $\mathrm{Cd}$ obtained in sediment samples were within the TWQR for both domestic and irrigation purposes. A similar high-concentration range of 0.01 to $0.26 \mathrm{mg} / \ell \mathrm{Cd}$ has been reported in the Umtata River (Fatoki et al., 2002). The river water flow rate as at the period of sampling could be regarded as normal. The higher level of Cd obtained in water samples relative to the amount in sediment might be due to contribution from other sources such as agricultural runoff where fertilisers are used in addition to

Percentage recoveries from spiked double-distilled water using the OBD method for the metals ranged from $91.6 \pm 0.003$ to $99.0 \pm$ 0.004 .

Recoveries from spiked double-distilled water using the LLE method with NaDDC as the ligand ranged from $71.2 \pm 0.002$ to 110.3 \pm 0.006 while that using APDC ranged from $75.3 \pm 0.001$ to 95.5 \pm 0.005 . The OBD method gave a relatively better and more consistent recovery, hence was applied to metal determination. Results of the recovery experiment for spiked pre-digested soil, sediment and vegetables are presented in Table 2. Mean recoveries for sediment and soil ranged between $88.2 \pm 0.004$ and $97.3 \pm 0.006$ and between $86.0 \pm 0.002$ and $98.4 \pm 0.005$ respectively. Acceptable possible release of sediment bound-metal. A higher Cd concentration range of between $0.008 \pm 0.003$ and $0.017 \pm 0.002 \mathrm{mg} / \ell$ in Tyume River has been previously reported (Fatoki and Awofolu, 2003).

Apart from natural sources, other probable sources of this metal in surface water include leaching from $\mathrm{Ni}$-Cd based batteries (Hutton et al., 1987), runoff from agricultural soils where phosphate fertilisers are used (Stoeppler, 1991) and other metal wastes. Levels of $\mathrm{Pb}$ in river water varied between $0.021 \pm 0.004$ and 0.035 $\pm 0.001 \mathrm{mg} / \ell$ and between $0.040 \pm 0.005$ and $0.067 \pm 0.003 \mathrm{mg} / \mathrm{kg}$ in sediment. The levels of $\mathrm{Pb}$ obtained in sediment were higher than those in the river water; hence the sediment could be an 
influential factor on the level of $\mathrm{Pb}$ in river water with other enhancing factors such as the current flow and $\mathrm{pH}$ since water acidity is known to influence the solubility and availability of metals. The TWQR for $\mathrm{Pb}$ in river water for domestic use is 0 to $0.01 \mathrm{mg} / \ell$ (DWAF, 1996a).

The range obtained in this study exceeds that of the TWQR, hence making the water unsuitable for domestic use. The use of the river water for drinking purposes by man and animals could lead to accumulation of the metal with resultant ill-health effects. Chronic exposure to $\mathrm{Pb}$ has been linked to growth retardation in children (Schwartz et al., 1986). Pb toxicity studies conducted on female mouse revealed mostly miscarriages, premature delivery and infant mortality (Taupeau et al., 2001). A concentration of $\mathrm{Pb}>0.1 \mathrm{mg} / \ell$ is detrimental to foetuses and children with possible development of neurological problems. A higher concentration range of 0.24 to $1.11 \mathrm{mg} / \ell$ of $\mathrm{Pb}$ in Umtata River has been reported by Fatoki et al., 2002. TWQR of 0 to $0.2 \mathrm{mg} / \ell$ and $0.1 \mathrm{mg} / \ell$ (DWAF, 1996c) has been set for $\mathrm{Pb}$ in river water for use in irrigation and livestock watering respectively. Levels obtained in this study were lower than these ranges, hence the water could still be used for both irrigation and livestock watering purposes as far as this parameter is concerned. The river water is not noticeably used for recreational purposes because its aesthetic state is unacceptable.

Concentration of Co in river water ranged from trace to 0.062 $\pm 0.002 \mathrm{mg} / \ell$ while in sediment, it varied from trace to $0.312 \pm 0.004$ $\mathrm{mg} / \mathrm{kg}$. Cobalt is regarded as an essential element and forms part of Vitamin $B_{12}$ required for red-blood cell synthesis. There is a wide margin of safety between toxic concentrations and nutritional requirement levels of Co. However, adverse chronic effects of Co ingestion at concentration $>2 \mathrm{mg} / \ell$ may occur (DWAF, 1996d). Toxic effects of Co include loss of body weight and depressed appetite. $2.0 \times 10^{-4} \mathrm{mg} / \ell$ is the typical concentration of Co in unpolluted surface water (DWAF, 1996d). The range obtained in this study exceeds this amount. However, the water could be said to be quite suitable for agricultural use and livestock watering since no adverse effect is observed even at TWQR of 0 to $1 \mathrm{mg} / \ell$. Elemental Co is not found in nature but exists variously as sulphide ores and in association with $\mathrm{As}, \mathrm{Fe}, \mathrm{Ni}$ and $\mathrm{Cu}$. Other possible sources in the river water include wastes from some metal alloys and cobalt salts in some pigments.

Levels of $\mathrm{Zn}$ in river water and sediment ranged between 0.097 \pm 0.005 and $0.431 \pm 0.002 \mathrm{mg} / \ell$ and $0.080 \pm 0.003$ to $0.491 \pm 0.004$ $\mathrm{mg} / \mathrm{kg}$ respectively (Table 3 ). The TWQR for Zn in water for domestic use is $3.0 \mathrm{mg} / \ell$ (DWAF, 1996a); hence, no detrimental effects from domestic water usage at the level obtained in this study are expected. The TWQR levels of $\mathrm{Zn}$ in water for safe aquatic ecosystem (DWAF, 1996b), irrigation and livestock watering (DWAF, 1996c) are $0.002 \mathrm{mg} / \ell, 0$ to $1.0 \mathrm{mg} / \ell$ and 0 to $20 \mathrm{mg} / \ell$ respectively. The water is unfit for the sustenance of the aquatic ecosystem but could still be utilised for irrigation and livestock watering since the range obtained was much lower than the TWQR values.

Levels of $\mathrm{Cu}$ in river water ranged from trace to $0.387 \pm 0.002$ $\mathrm{mg} / \ell$ while that in sediment ranged from $0.082 \pm 0.007$ to $0.496 \pm$ $0.004 \mathrm{mg} / \mathrm{kg}$. The South African guideline for $\mathrm{Cu}$ in domestic water supply is 0 to $1.0 \mathrm{mg} / \ell$ (DWAF, 1996a). The range obtained was lower than the set value, hence adverse effects from domestic use are not expected as far as this parameter and the results obtained are concerned. At neutral or alkaline $\mathrm{pH}$, typical concentration of $\mathrm{Cu}$ in surface water is $0.003 \mathrm{mg} / \ell$ (DWAF, 1996a). The TWQR levels of $\mathrm{Cu}$ for irrigation and livestock watering are 0 to $0.2 \mathrm{mg} / \ell$ and 0 to $5.0 \mathrm{mg} / \ell$ respectively with adverse chronic effects expected at 1 to $10 \mathrm{mg} / \ell$ depending on the livestock (DWAF, 1996c). The water is unsuitable for the maintenance of the aquatic ecosystem; however, $\mathrm{Cu}$ is not expected to cause any problem if the water is utilised for irrigation and livestock watering.

Levels of $\mathrm{Ni}$ in river water ranged from $0.201 \pm 0.003$ to 1.777 $\pm 0.002 \mathrm{mg} / \ell$ and from $0.401 \pm 0.006$ to $0.981 \pm 0.007 \mathrm{mg} / \mathrm{kg}$ in sediment. More attention has been focused on the toxicity of $\mathrm{Ni}$ in low concentrations, such as the fact that $\mathrm{Ni}$ can cause allergic reactions and that certain $\mathrm{Ni}$ compounds may be carcinogenic (McKenzie and Smythe, 1998). The typical concentrations of Ni in unpolluted surface water are given as $5.0 \times 10^{-4} \mathrm{mg} / \ell$ (DWAF, 1996d) and 0.015 to $0.020 \mathrm{mg} / \ell$ (Salnikow and Denkhaus, 2002). The range obtained in this study was much higher, indicating that the water is contaminated. All Ni compounds except for metallic Ni have been classified as carcinogenic to humans (IARC, 1990). Possible sources of $\mathrm{Ni}$ in surface water include anthropogenic sources, combustion of fossil fuels (Merian, 1984), old battery wastes, components of automobiles, old coins, and many other items containing stainless steel and other Ni alloys. Among the known health-related effects of $\mathrm{Ni}$ are skin allergies, lung fibrosis, variable degrees of kidney and cardiovascular system poisoning and stimulation of neoplastic transformation.

Some physical parameters determined in the river water and sediment are presented in Table 4 . The $\mathrm{pH}$ of the river water ranged between 6.93 and 7.15 while that of sediment varied between 5.85 and 7.21. The ranges fell within the TWQR (6 to 9) for $\mathrm{pH}$ in water intended for domestic use (DWAF, 1996a). Water acidity is known to influence the solubility, availability and toxicity of metals in the aquatic ecosystems.

The organic matter content of sediment and soil ranged between 0.11 to $1.13 \%$ and 0.72 to $1.29 \%$ respectively (Tables 4 and 5). Organic matter (OM) is usually the organic fraction of decomposed plant and animal residues, which plays important role in water retention, aggregation and soil structure. It is a measure of soil fertility and could also affect the mobility of metals from soil to plants. Typical amounts of OM in soil vary from $<1 \%$ in ordinary soil to $90 \%$ in bog peat soil and between $1 \%$ to $20 \%$ in mineral soils (Radojevic and Bashkin, 1999). OM values obtained in both sediment and soil were within this range. The relevance of OM to this study is its influence on mobility and flux of trace metals. The normal range of OM obtained signifies that the metals in soil and sediment are bio-available since trace metals are known to form complexes with organic matter which influences their availability (Sauve et al., 1998). Cu and $\mathrm{Pb}$ form very stable complexes with dissolved organic matter, and only a very small fraction of these metals exists as free hydrated metal ions, when soil $\mathrm{pH}$ is not strongly acid (Aualiitia and Pickering, 1986; Sauve et al., 1998).

\begin{tabular}{|c|c|c|c|}
\hline \multicolumn{4}{|c|}{$\begin{array}{c}\text { TABLE4 } \\
\text { Some physical parameters of freshwater and } \\
\text { sediment samples }\end{array}$} \\
\hline $\begin{array}{c}\text { Sampling } \\
\text { dates }\end{array}$ & $\begin{array}{c}\text { Organic } \\
\text { matter (\%) } \\
\text { (sediment) }\end{array}$ & Sediment & River water \\
\hline $22 / 07 / 03$ & 1.13 & $5.85 \pm 0.002$ & $6.93 \pm 0.004$ \\
$25 / 08 / 03$ & 1.01 & $6.48 \pm 0.001$ & $7.15 \pm 0.005$ \\
$19 / 09 / 03$ & 0.58 & $7.21 \pm 0.003$ & $7.02 \pm 0.003$ \\
$02 / 10 / 03$ & 0.11 & $6.88 \pm 0.003$ & $6.94 \pm 0.002$ \\
\hline$*$ Values are mean of three determinations \\
\hline
\end{tabular}


TABLE5

*Levels $(\mu \mathrm{g} / \mathrm{g} \pm \mathrm{SD})$ of trace metal in vegetables (cabbage and spinach) and soil samples from farmland with some physical parameters

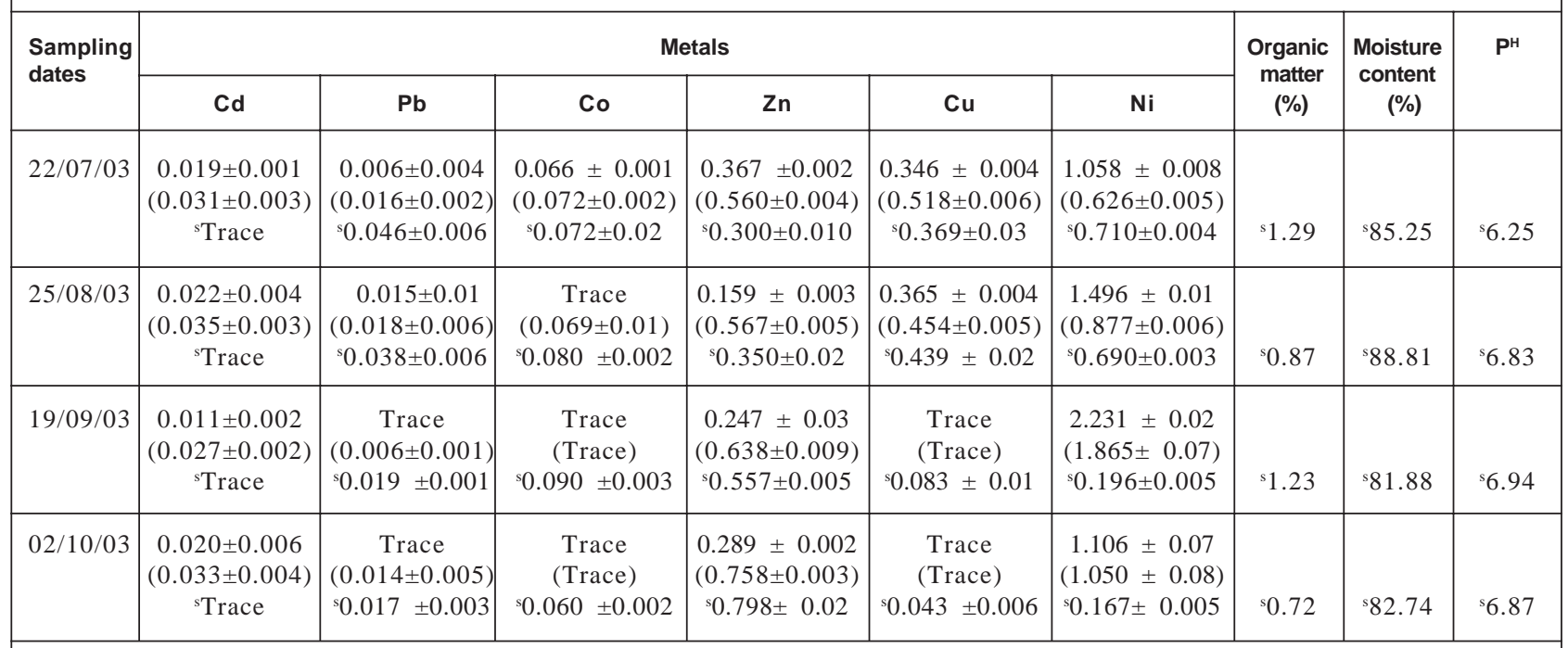

*Values are mean of triplicate analyses; values in parentheses are for spinach and values in superscript (s) are for soil samples

Results of trace metal analyses in vegetables (cabbage and spinach) and in soil samples with some physical parameters of soil are presented in Table 5. The mean concentrations of metals in cabbage ranged from $0.011 \pm 0.002$ to $0.022 \pm 0.004 \mathrm{mg} / \mathrm{kg}$; trace to $0.015 \pm 0.01 \mathrm{mg} / \mathrm{kg}$; trace to $0.066 \pm 0.01 \mathrm{mg} / \mathrm{kg} ; 0.159 \pm 0.003$ to $0.367 \pm 0.02 \mathrm{mg} / \mathrm{kg}$; trace to $0.365 \pm 0.04 \mathrm{mg} / \mathrm{kg}$ and $1.058 \pm 0.008$ to $2.231 \pm 0.02 \mathrm{mg} / \mathrm{kg}$ for $\mathrm{Cd}, \mathrm{Pb}, \mathrm{Co}, \mathrm{Zn}, \mathrm{Cu}$ and Ni respectively.

Mean metal levels in spinach varied between $0.027 \pm 0.002$ to $0.035 \pm 0.003 \mathrm{mg} / \mathrm{kg} ; 0.006 \pm 0.001$ to $0.018 \pm 0.006 \mathrm{mg} / \mathrm{kg}$; trace to $0.072 \pm 0.002 \mathrm{mg} / \mathrm{kg} ; 0.560 \pm 0.004$ to $0.758 \pm 0.003 \mathrm{mg} / \mathrm{kg}$; trace to $0.518 \pm 0.006 \mathrm{mg} / \mathrm{kg}$ and $0.626 \pm 0.005$ to $1.865 \pm 0.07 \mathrm{mg} / \mathrm{kg}$ in the same metal order as above. Levels of trace metals obtained in soil samples also ranged from trace for $\mathrm{Cd} ; 0.017 \pm 0.003$ to $0.046 \pm 0.006$ $\mathrm{mg} / \mathrm{kg} ; 0.060 \pm 0.002$ to $0.090 \pm 0.03 \mathrm{mg} / \mathrm{kg} ; 0.300 \pm 0.01$ to 0.798 $\pm 0.02 \mathrm{mg} / \mathrm{kg} ; 0.043 \pm 0.06$ to $0.439 \pm 0.02 \mathrm{mg} / \mathrm{kg}$ and $0.167 \pm 0.005$ to $0.710 \pm 0.004 \mathrm{mg} / \mathrm{kg}$ also in the same metal order as above. These values generally indicate the presence of the analysed metals in vegetable samples that might have been taken up from the soil. However, contribution to the metal levels in vegetables from the river water is highly probable since the farmland is irrigated with river water. The levels of the metals in vegetables were within the normal range (Table 6) for metals in plant leaves and much lower than the toxic level, hence consumption of the vegetables should not be of concern. The range of $\mathrm{Cd}$ and $\mathrm{Pb}$ obtained in the vegetable samples were lower than the range in river water while the ranges of Co, Zn, $\mathrm{Cu}$ and $\mathrm{Ni}$ in vegetables were relatively higher than those in river water.

The metal levels in soil were higher than those in the river water and vegetables with the exception of Ni. Plants are known to take up and accumulate trace metals from contaminated soils (Singh and Narwal, 1984; Bojakowska and Kochany, 1985; Pulford and Watson, 2003; Madejon et al., 2003), hence detection in vegetable samples was not surprising. Although levels of $0.022 \mathrm{mg} / \mathrm{kg}$ and $0.015 \mathrm{mg} /$ $\mathrm{kg}$ of $\mathrm{Cd}$ and $\mathrm{Pb}$ in cabbage and $0.035 \mathrm{mg} / \mathrm{kg}$ and $0.018 \mathrm{mg} / \mathrm{kg}$ in spinach respectively are within the normal range in plant leaves (Table 6), continual consumption could lead to accumulation with adverse health implications since Cd has been linked to renal diseases and cancer (Kjellstroem, 1986).

\begin{tabular}{|l|c|c|}
\hline \multicolumn{3}{|c|}{ TABLE 6} \\
$\begin{array}{c}\text { Normal and phytotoxic levels }(\mu \mathrm{g} / \mathrm{g}) \\
\text { of metals found in plant leaves }\end{array}$ \\
\hline $\begin{array}{l}\text { Trace } \\
\text { metal }\end{array}$ & $\begin{array}{c}\text { Normal } \\
\text { range }\end{array}$ & Toxicity \\
\hline $\mathrm{Cd}$ & $0.1-2.4$ & $5-30$ \\
$\mathrm{~Pb}$ & $5-10$ & $30-300$ \\
$\mathrm{Co}$ & - & - \\
$\mathrm{Zn}$ & $1-400$ & $100-400$ \\
$\mathrm{Cu}$ & $5-20$ & $20-100$ \\
$\mathrm{Ni}$ & $0.02-5$ & $10-100$ \\
\hline \multicolumn{3}{|c|}{ Source: Bowen (1979) } \\
\hline
\end{tabular}

\section{Conclusions}

The study revealed that open-beaker digestion is still a reliable method for quantitative determination of trace metals in environmental samples. The microwave-assisted digestion method also gave acceptable recoveries and is thus applicable for trace metal determination in vegetable samples. Elevated levels of $\mathrm{Cd}$ and $\mathrm{Pb}$ were detected in the river, which could be directly detrimental to the health of the aquatic ecosystem and indirectly to man since the river water is used to irrigate a nearby farmland. Metals from river water could be a contributing source to the levels in vegetables, hence continual assessment is highly essential.

\section{Acknowledgement}

The authors would like to thank Mr. Farai Dondofema of the Department of GIS and Remote Sensing, University of Fort Hare for the assistance towards mapping of the sampling area. 


\section{References}

AGEMIAN H and CHAU ASY (1976) Evaluation of extraction techniques for the determination of metals in aquatic sediments. Anal. 101 761-767.

ALABASTER JS and LLOYD R (1980) Water Quality Criteria for Fish $\left(2^{\text {nd }}\right.$ edn.) London, Butterworths.

AUALIITIA TU and PICKERING WF (1986) Anodic stripping voltammetric study of the lability of $\mathrm{Cd}, \mathrm{Pb}, \mathrm{Cu}$ ions sorbed on humic acid particles. Water Res. 20 1397-1406.

BATTERHAM GJ, MUNKSGAARD NC and PARRY DL (1997) Determination of trace metals in seawater by inductively coupled plasma mass spectrometry after off-line dithiocarbamate solvent extraction. J. Anal. At. Spectrom. 12 1277-1280.

BECKER A, KLOCK W, FRIESE K, SCHRECK P, TREUTLER HC, SPETTEL B and DUFF MC (2001) Lake Suber See as a natural sink for heavy metals from copper mining. J. Geochem. Explor. 74 (1-3) 205-217.

BOJAKOWSKA IA and KOCHANY J (1985) Studies of the removal of heavy metals from sludges by leaching and uptake by plants. J. Plant Soil 86 299-302.

BORGMANN U (1983) Metal speciation and toxicity of free metal ions to aquatic biota. In: Nriagu JO (ed.) Aquatic Toxicity, Advances in Environmental Science and Technology. Vol. 13 John Wiley \& Sons, New York. 47-73.

BOWEN HJM (1979) The Environmental Chemistry of the Elements. Academic Press, London.

DEPARTMENT OF WATER AFFAIRS \& FORESTRY, DWAF (1992) Analytical Methods Manual TR151. Hydrological Research Institute, DWAF, Pretoria.

DEPARTMENT OF WATER AFFAIRS \& FORESTRY, DWAF (1996a). Water Quality Guidelines, Domestic Use. Vol. 1 (2 ${ }^{\text {nd }}$ edn.) DWAF, Pretoria.

DEPARTMENT OF WATER AFFAIRS \& FORESTRY, DWAF (1996b) Water Quality Guidelines, Aquatic Ecosystem Use. Vol. 7 ( $1^{\text {st }}$ edn.) DWAF, Pretoria.

DEPARTMENT OF WATER AFFAIRS \& FORESTRY, DWAF (1996c) Water Quality Guidelines, Agricultural Use and Livestock Watering. Vol. 5 ( $2^{\text {nd }}$ edn.) DWAF, Pretoria.

DEPARTMENT OF WATER AFFAIRS \& FORESTRY, DWAF (1996d) South African Water Quality Guidelines, Field Guide. Vol. 8 (1 $1^{\text {st }}$ edn.) DWAF, Pretoria.

FATOKI OS, LUJIZA N and OGUNFOWOKAN AO (2002) Trace metal pollution in Umtata River. Water SA 28 (2) 183-190.

FATOKI OS and MATHABATHA S (2001) An assessment of heavy metal pollution in the East London and Port Elizabeth harbours. Water SA 27 (2) 233-240.

FATOKI OS (1993) Levels of dissolved Zinc and Cadmium in some surface waters of Western Nigeria. Environ. Pollut. 19 285-289

FATOKI OS and AWOFOLU OR (2003) Levels of Cd, Hg and Zn in some surface waters from the Eastern Cape Province, South Africa. Water SA 29 (4) 375-380.

FIACCABRINO GC, DE-ROJI NF and KOUDELKA-HEP M (1998) Gel-integrated microelectrode arrays for direct voltammetric measurements of heavy metals in natural waters and other complex media. Anal. Chem. 70 (14) 2949-2956.

GOERING PL, WAALKES MP and KLAASSEN CD (1994) Toxicology of metals. In: Goyer RA and Cherian MG (eds.) Handbook of Experimental Pharmacology. Vol. 115, Springer, New York. $189 \mathrm{pp}$.

GARCIA EM, CABRERA C, SANCHEZ J, LORENZO ML and LOPEZ MC (1999) Chromium levels in potable water, fruit juices and soft drinks: influence on dietary intake. Sci. Total Environ. 241 (1-3) 143-150.

GULSON BL, SHEEHAN A, GIBLIN AM, CHIARADIA M and CONRADT B (1997) The efficiency of removal of lead and other elements from domestic drinking waters using a bench-top water filter system. Sci. Total Environ. 196 (3) 205-216.

HALL GE, PELCHAT JC and VAIVE JE (2002) Sample collection, filtration and preservation protocols for the determination of 'total dissolved' mercury in waters. Anal. 127 674-680.
HESS R and SCHMID B (2002) Zinc supplement overdose can have toxic effects. J. Paediatr. Haematol./Oncol. 24 582-584.

HUTTON M, CHANEY RL, KRISHNA CR, MURTI M, OLADE A and PAGE AL (1987) Group Report In: Hutchinson TC and Meema KM (eds.) Lead, Mercury, Cadmium and Arsenic in the Environment. John Wiley, New York. 35-41.

HOLYNSKA B, OSTACHOWICZ B and WEGRZYNEK D (1996) Simple method of determination of copper, mercury and lead in potable water with preliminary pre-concentration by total reflection X-ray fluorescence spectrometry. Spectrochim. Acta Part B: At. Spectrosc. 51 (7) 769-773.

INTERNATIONAL AGENCY FOR RESEARCH ON CANCER (IARC) (1990) Monographs on the Evaluation of Carcinogenic Risks to Humans: Chromium, Nickel and Welding 49 IARC, Lyon. 45 pp.

KJELLSTROEM T (1986) Itai-itai disease. In: Friberg L, Elinder CG, Kjellstroem T and Nordberg GF (eds.) Cadmium and Health: A Toxicological and Epidemiological Appraisal Vol. 11, Effects of Response. CRC Press, Boca Raton, Florida. 257-290.

MADEJON P, MURILLO JM, MARANON T, CABRERA F and SORIANO MA (2003) Trace element and nutrient accumulation in sunflower plants two years after the Aznalcollar mine spill. Sci. Total Environ. 307 (1-3) 239-257.

McKENZIE HA and SMYTHE LE (1998) Quantitative Trace Analysis of Biological Materials. Elsevier, Amsterdam.

MERIAN E (ed.) (1991) Metals and their Compounds in the Environment. Occurrence, Analysis and Biological Relevance. UCH, Weinheim-New York-Basel-Cambridge.

MERIAN E (1984) Introduction on environmental chemistry and global cycles of chromium, nickel, cobalt, beryllium, arsenic, cadmium, and selenium, and their derivatives. Toxicol. Environ. Chem. 8 9-38.

MOHAN BS and HOSETTI BB (1998) Lead toxicity to Salvinia natans grown in macrophyte ponds. J. Ecotoxicol. Environ. Monit. $813-7$.

O’NEIL P (1993) Environmental Chemistry. Chapman and Hall, London. 193 pp.

ONYARI MJ, MUOHI AW, OMONDI G and MAVUTI KM (2003) Heavy metals in sediments from Makupa and Port-Reitz Creek systems: Kenyan Coast. Environ. Int. 28 (7) 639-647.

PANE EF, RICHARDS JG and WOOD CM (2003) Acute waterborne nickel toxicity in the rainbow trout (Oncorhynchus mykiss) occurs by a respiratory rather than ionoregulatory mechanism. Aquat. Toxicol. 63 (1) 65-82.

PRATER BE (1975) The metal content and characteristics of Steelwork effluents discharging to the Tees estuary. Water Pollut. Control 74 63-78.

PREUSS E and KOLLMAN H (1974) Metallgehalte in Klarschlammen. Naturwissenschafter 61 270-274.

PULFORD ID and WATSON C (2003) Phytoremediation of heavy metal-contaminated land by trees - A review. Environ. Int. 29 (4) 529-540.

RADOJEVIC M and BASHKIN VN (1999) Organic matter. In: Practical Environmental Analysis. The Royal Society of Chemistry, Cambridge. 325-329.

SALNIKOW K and DENKHAUS E (2002) Nickel essentiality, toxicity, and carcinogenicity. Crit. Rev. Oncol./Haematol. 42 (1) 3556.

SAUVE S, McBRIDE MB and HENDERSHOT W (1998) Soil solution speciation of lead (II): Effects of organic matter and pH. Soil Sci. Soc. Am. J. 62 618-621.

SCHWARTZ J, ANGLE C and PITCHER H (1986) Relationship between childhood blood lead levels and stature. Pediatr. 77 281288.

SHRIADAH MMA (1999) Heavy metals in mangrove sediment of the United Arab Emirates shoreline (Arabia Gulf). Water Air and Soil Pollut. 116 523-534.

SINGH BR and NARWAL RP (1984) Plant availability of heavy metals in a sludge-treated soil: II metal extractability compared with plant metal uptake. L. Environ. Qual. 13 344-348.

SPEAR PA (1981) Zinc in the Aquatic Environment; Chemistry, Distribution and Toxicity. National Research Council of Canada, 
Association Committee on Scientific Criteria for Environmental Quality, Report NRCC No. 17589, Ottawa.

STOEPPLER M (1991) Cadmium. In: Merian E (ed.) Metals and their Compounds in the Environment: Occurrence, Analysis and Biological Relevance. VCH, New York. 803-851.

TAUPEAU C, POUPON J, NOME F and LEFEVRE B (2001) Lead accumulation in the mouse ovary after treatment-induced follicular atresia. Reproductive Toxicol. 15 (4) 385-391.

TEO KC and CHEN J (2001) Determination of cobalt and nickel in water samples by flame atomic absorption spectrometry after cloud point extraction. Anal. Chim. Acta 434 (2) 325-330.

TESSIER A, CAMPBELL PGC and BISSON M (1979) Sequential extraction procedure for the speciation of particulate trace metals. Anal. Chem. 51 844-851

TYLER TG (1981) Heavy metals in soil biology and biochemistry. In:
Paul EA and Ladd JN (eds.) Soil Biochemistry. Marcel Dekker, New York. 33 pp.

UNITED STATES ENVIRONMENTAL PROTECTION AGENCY (USEPA) (1986a) Quality Criteria for Water. United States Environmental Protection Agency office of Water Regulations and Standards. Washington DC, 20460.

UNITED STATES ENVIRONMENTAL PROTECTION AGENCY (USEPA) (1986b) Quality Criteria for Water. Office of Water Regulation and Standards, Washington DC, USEPA-40015-86001. 256 pp.

VAN LOON JC (1982) Chemical Analysis of Inorganic Constituent of Water. CRC Press.

WOODWORTH JC and PASCOE V (1982) Cadmium toxicity to rainbow trout, Salmon gairdneri Richardson. A study of eggs and alevins. J. Fish. Biol. 21 47-57. 